\title{
EL PROBLEMA DE LA RELACIÓN \\ DE CAUSALIDAD EN EL DERECHO \\ DE LA RESPONSABILIDAD CIVIL
}

\author{
THE PROBLEM OF CAUSATION
}

IN THE LAW OF CIVIL LIABILITY

\section{O PROBLEMA DA RELAÇÃO \\ DE CAUSALIDADE NO DIREITO DA RESPONSABILIDADE CIVIL}

\author{
Juan Manuel Prevot
}

\section{RESUMEN}

Tanto desde el punto de vista teórico como del práctico, la relación de causalidad es, sin duda, el presupuesto más problemático y, quizá, menos tratado del Derecho de la Responsabilidad Civil. Enrevesada, difícil, compleja, tormentosa, insoluble, angustiosa, multiforme, enigmática y ambigua, son algunas de las características (o adjetivos calificativos) con que, comúnmente, se señalan las cualidades (más bien abstractas) atribuidas a la causalidad (en tanto sustantivo). No obstante, la distinción entre causalidad e imputación objetiva resurgida en los últimos años y de gran predicamento en el Derecho Penal, aporta un halo de aire fresco que no se puede soslayar.

Palabras clave: causalidad, autoría del daño, extensión del resarcimiento

\section{SUMMARY}

From both the theoretical and practical perspectives, causation is undoubtedly the thorniest and perhaps least-addressed issue in civil liability law. Convoluted, difficult, complex, turbulent, insoluble, distressing, multiface-

* Docente adjunto de Derecho Civil II (Obligaciones) en la Facultad de Ciencias Jurídicas y Sociales de la UCU, provincia de Entre Ríos. Dirección postal: Rosario No 120 , ciudad de Gualeguaychú, Entre Ríos. Artículo recibido el 4 de agosto de 2010 y aceptado para su publicación el 30 de septiembre de 2010 Correo electrónico: manuelprevot@hotmail.com. 
ted, enigmatic and ambiguous are some of the features (or adjectives) that commonly identify the qualities (abstract) attributed to causality (as noun). Nevertheless, the distinction between causality and objective imputation has re-emerged with considerable fanfare in recent years in Criminal Law, providing a breath of fresh air well worth examining.

Keywords: causality, authorship, length of recovery.

\section{Resumo}

Tanto desde o ponto de vista teórico, quanto desde o ponto de vista prático, a relação de causalidade é, sem dúvida, o pressuposto mais problemático e, quem sabe, menos tratado do Direito da Responsabilidade Civil. Arrevesada, difícil, complexa, tormentosa, insolúvel, angustiosa, multiforme, enigmática e ambígua, são algumas das características (os adjetivos qualificativos) com que, comumente, se assinalam às qualidades (mais bem abstratras) atribuídas à causalidade (no entanto substantivo). No obstante, a distinção entre causalidade e imputação objetiva ressurgida nos últimos anos e de grande prestígio no Direito Penal, contribui a uma coroa de ar fresco que não se pode esguelhar.

Palavras clave: causalidade, autoria, extensão de indenização.

\section{§ I. CARACTERES Y PERPLEJIDADES ${ }^{1}$}

\section{La causalidad:} una noción difícil y enrevesada de la responsabilidad civil

Pocos temas se han presentado más enrevesados y plagados de dificultades que éste. De ahí que sea una de las cuestiones más "complejas"2; "tor-

${ }^{1}$ Como previo, hemos de aclarar al lector que la temática aquí abordada (esto es, el nexo de causalidad en el Derecho de la Responsabilidad Civil), presenta aristas comunes en todos los sistemas forjados a la sazón de la cultura grecorromana y, si se quiere, también a los sistemas de raíces anglosajonas (Common Law). De allí que las cuestiones atinentes a la relación de causalidad (en tanto presupuesto de la responsabilidad civil) resultan comunes, en principio, a todos los ordenamientos jurídicos.

${ }^{2}$ Alain NADEAU, "Notes sur le lien de causalité et sa preuve dans les actions en responsabilité civile", dans Univversité DE MontréAL, Études juridiques en hommage à Monsieur le juge Bernard Bissonnette, Montréal, Presses de l'Université de Montréal, 1963, p. 435, Philippe Conte, Patrick Maistre du Chambon, La responsabilité civile délictuelle, Grenoble, Presses Universitaires de Grenoble, 2000, p. 131. 
mentosas"3; "angustiosas"4; "irritantes"5; "enigmáticas"6; "multiformes"; "ambiguas"; "insolubles"9 o, si se prefiere, "de extrema dificultad" 10 (práctico-teórica $^{11}$ ) del Derecho de la Responsabilidad Civil. A punto tal que, para reconocidos autores ${ }^{12}$, los jueces deberían abstenerse de realizar cualquier análisis de índole causal; puesto que el problema siempre queda reducido a una mera quaestio facti, librada en ultima ratio a la sensibilidad ${ }^{13}$, la equidad ${ }^{14}$, el sentido común ${ }^{15}$ o, en suma, al prudente arbitrio del intérprete ${ }^{16}$.

\section{La causalidad:}

una noción que trasciende el ámbito de la responsabilidad civil

La noción de causalidad en derredor de la cual giran una pléyade de principios, corrientes y doctrinas (filosóficas, físicas, jurídicas, matemáticas, etc.), no sólo desborda el campo de la responsabilidad civil sino, también, el del Derecho aprehendido en su total dimensidad. Es así que la causalidad siempre atrajo la atención del filósofo, del físico, del matemático, del

${ }^{3}$ Giulio Ponzanelui, La responsabilità civile. Profili di diritto comparato, Bologna, Il Mulino, 1996, p. 88.

4 Paul Esmein, "Le nez de Cléopâtre ou les affres de la causalité", Dalloz, Cronique, Paris, 1964, p. 205.

${ }^{5}$ Georges Durry, "Commentaires sur l'échec de la division civile $(2$ e $)$ de la cour d'appel. $2^{\circ}$, 12/12/1968”, in RTDciv., No 1, Paris, 1969, p. 570.

${ }^{6}$ Christian Lapoyade-Deschamps, "La reparation du préjudice économique pur en Droit français", dans Revue Internationale de Droit comparé, No 2, Paris, 1998, p. 367.

7 Olivia SABARD, La cause étrangère dans les Droits privé et public de la responsabilité extracontractuelle; Paris, Librairie Générale de Droit et de Jurisprudence, 2007, p. 367.

${ }^{8}$ Cesare SAlvi, La responsabilità civile, Milano, Giuffre editore, 1998, p. 169.

${ }^{9}$ Georges Ripert, La règle morale dans les obligations civiles, $3{ }^{a}$ éd., Paris, Librairie Générale de Droit et de Jurisprudence, 1935, p. 225, José TовÍAs, "La relación de causalidad en la responsabilidad civil médica”, en Revista de Responsabilidad Civil y Seguros, s/vol., Buenos Aires, 2003, p. 39.

${ }^{10}$ Jean-Louis Baudouin, Patrice Deslauriers, La responsabilité civile, Québec, Éditions Yvos Blais, 2007, vol. 1: Principes généraux, p. 617, Clothilde GRARE, Recherches sur la cohérence de la responsabilité délictuelle. L'influence des fondements de la responsabilité sur la réparation, Paris, Dalloz, 2005, p. 67.

${ }^{11}$ Boris Starck, Henri Roland, Laurent Boyer, Obligations, $5^{\mathrm{a}}$ éd., Paris, Litec, 1996, tome 1: Responsabilité délictuelle, p. 437.

${ }^{12}$ Ripert (n. 9), p. 219 et ss.

${ }^{13} \operatorname{Esmein}($ n. 4), p. 205.

${ }^{14}$ Guillaume CANCELIER, "De l'explication causale en Droit de la responsabilité civile délictuelle", in RTDciv., N 1, Paris, 2010, p. 53.

${ }^{15}$ Giovanni VAlCAVI, "Sulla causalità giuridica nella responsabilità civile da inadempienza e da illecito", in Rivista di Diritto Civile, No 2, Padova, 2001, p. 409 e ss.

16 "El juez tiene un amplio campo de apreciación", en Jean CARbonnier, Droit civil, 15 éd., Paris, Presses Universitaires de France, 1991, volume 4: Les obligations, p. 371. 
literato, del religioso, del legislador, etc.; congregar nombres propios aquí, es delatar omisiones.

Sin embargo, he aquí que la noción de causa y de nexo causal es una conquista de tiempos recientes. La idea de que los hechos están determinados por las leyes de la naturaleza se halla fuera de la sique del hombre primitivo; que bajo un alto predominio del componente emocional no buscaba una explicación racional del suceder de los hechos (esto es, no sentía la necesidad de realizar una investigación causal de los acontecimientos); se contentaba, más bien, con encontrar un responsable ${ }^{17}$.

\section{La causalidad: una noción dual de la responsabilidad civil}

La causalidad cumple en el Derecho de la Responsabilidad Civil dos funciones:

1) Una relativa a la imputación del hecho dañoso a su autor o, si se prefiere, tendiente a la individualización del responsable ${ }^{18}$, denominada por buena parte de la doctrina autoral italiana como "causalidad material" y,

2) Otra, consistente en determinar el contenido de la obligación resarcitoria, conocida como "causalidad jurídica" 19 .

Una cosa es, entonces, emplear la causalidad a los fines de imputar el evento lesivo a un sujeto (causalidad como requisito autónomo de la responsabilidad), y otra muy distinta es utilizar la causalidad para determinar la medida de la reparación (causalidad como complemento ${ }^{20}$. En el primer caso, se responde al interrogante, ¿quién causó el daño? (etapa del an respondeatur). Mientras que en el segundo, se responde a la pregunta, ¿cuánto debe pagar el responsable? (etapa del quantum respondeatur) ${ }^{21}$.

Esta doble función que cumple la causalidad en el ámbito de la responsabilidad civil, junto a las diversas formas que forzosamente adquiere

\footnotetext{
${ }^{17}$ Hans Kelsen, Sociedad y naturaleza. Una investigación sociológica, Buenos Aires, Depalma, 1945 , pp. 1, 7, 10, 18, 357, 383 y ss.

${ }^{18}$ Francesco Realmonte, Il problema del rapporto di causalità nel risarcimento del danno, Milano, Giuffrè editore, 1967, p. 154.

${ }^{19}$ Aunque la expresión utilizada no es del todo correcta, Realmonte (n. 18), p. 42. Sobre los diversos modos con que se usa la voz "causalidad jurídica”, véase Gino GorLA, "Sulla cosiddetta causalità giuridica: 'fatto dannoso e conseguenza'", in Studi in onore di Antonio Cicu, vol. 1, Milano, Giuffrè editore, 1951, p. 436 e ss., Andrea Belvedere, "Causalità giuridica?", in Rivista di Diritto Civile, vol. I Padova, 2006, p. 7 e ss.

${ }^{20}$ Gorla (n. 19), p. 433 e ss.

${ }^{21}$ Aunque es importante aclarar que el quantum respondeaturno se agota en la causalidad. Adriano de CuPIS, "Il problema giuridico del 'quantum respondeatur" ", in Rivista di Diritto Civile, vol. I, Padova, 1967, p. 540.
} 
la misma, según el ámbito o fattispecie en que opere, imposibilitan todo intento de reconstrucción unitaria.

\section{La causalidad: un requisito esencial de la responsabilidad civil}

Es común la opinión de que la relación de causalidad entre la conducta del accionado y el hecho dañoso es una de las condiciones imprescindibles de la responsabilidad civil. Es que, pues, el sentido común se niega a admitir la existencia de un daño que deba ser soportado por quien no ha contribuido a su realización ${ }^{22}$.

\section{La causalidad:}

una noción plausible de confusiones, incoherencias, deformaciones y usos impropios

Fruto de la incoherencia e ilogicidad que prima, tiempo ya, en el Derecho de la Responsabilidad Civil, amén de su ya remarcada complejidad, la relación de causalidad es, por lo general, escamoteada ${ }^{23}$, confundida o malograda. Veamos algunas de las razones:

\section{5. a) Pluralidad de causas}

Con gran frecuencia el daño deriva de una serie concatenada de acontecimientos, o lo que es igual, de una pluralidad muy diversa de $\operatorname{causas}^{24}$; y todas ellas, con independencia de que sean directas o indirectas, remotas o próximas, constituyen un antecedente sin el cual el resultado final no se hubiese verificado ${ }^{25}$. Cuando esto sucede, el práctico del Derecho se encuentra ante la encrucijada de establecer a cuál o, a cuáles, de todas estas causas (o condiciones), corresponde atribuir relevancia jurídica. La complejidad del asunto proviene de que los hechos no aparecen perfectamente dibujados, sino que, de ordinario, integran un conjunto o masa de acontecimientos que actúan como factores determinantes, condicionantes o coadyuvantes de sucesivos fenómenos, y que se interfieren recíprocamente en sus respectivas derivaciones, de manera de presentar un

${ }^{22}$ André Brun, Responsabilité civile extracontractuelle, Paris, Litec, 2005, p. 141.

${ }^{23}$ Denis Mazeaud, "Famille et responsabilité (Réflexions sur quelques aspects de 'l'idéologie de la réparation')", dans Études offertes à Pierre Catala. Le Droit privé français à la fin du XX siècle, Paris, Litec, 2001, volume I: Partie générale, p. 571.

${ }^{24}$ Jorge Mosset IturRaspe, Responsabilidad por daños, Santa Fe, Rubinzal Culzoni, 2004, p. 230 .

${ }^{25}$ François Chabas, Linfluence de la pluralité de causes sur le Droit a réparation, Paris, Librairie Générale de Droit et de Jurisprudence, 1967, p. 2 et ss. 
panorama borroso que dificulta descubrir el nexo de causalidad que se está indagando ${ }^{26}$.

De ahí que, a los efectos de poder establecer un criterio jurídico-valorativo que permita delimitar el problema y erigir, por consiguiente, a la categoría de causa, uno o unos de los tantos antecedentes que coadyuvan a la producción del resultado final nocivo (daño), se han formulados diversas teorías que, a la postre de sus diversas interpretaciones, no hacen más que enturbiar la cuestión (por ejemplo, causa próxima, causalidad adecuada, causa eficiente, condición preponderante, condición necesaria, etcétera) ${ }^{27}$.

\section{5. b) La confusión entre culpa y causa.}

La confusión entre el juicio sobre la culpabilidad (cuando se la aprehende en clave objetiva) y el juicio sobre la causalidad (cuando se la escruta bajo los cánones de la adecuación) es innegable, y las consecuencias, de recibo, no son menores ${ }^{28}$. Al respecto, nos explayamos en el acápite $\S$ II, 2 , b).

\section{5. c) La confusión entre causalidad, imputabilidad} y atribución

Por otro lado, las nociones de "imputación”, "atribución” e "imputabilidad", son giros que aparecen entremezclados cuando se aborda tanto: la relación de causalidad (donde la distinción entre causalidad e imputación ha sabido concitar la atención de prestigiosa doctrina autoral ${ }^{29}$; como la culpabilidad (dado que la imputabilidad es un requisito previo e indispensable); los factores de atribución (que también son llamados, por muchos, criterios de imputación) y la noción misma de responsabilidad (puesto que algunos la definen como la imputación de un hecho dañoso a un sujeto).

${ }^{26}$ Jorge Llambías, "El Derecho no es una física de las acciones humanas", en La Ley, tomo 107, Buenos Aires, 2009, p. 1.015.

${ }^{27}$ Una "pluralidad de formulaciones jurídicas" en palabras de Roger MisLawsKi, $L a$ causalité dans la responsabilité civile. Recherches sur ses rapports avec la causalité scientifique, thesè pour le doctorat de L'Université de Cergy-Pontoise, Paris, 2006, p. 391.

${ }^{28}$ Jorge MAYo, Estudios de Derecho civil, Buenos Aires, La Ley, 2005, p. 230 y ss.; Aníbal PiagGio, "Presencias de la culpa”, en La Ley, tomo F, Buenos Aires, 2005, p. 1.444.

${ }^{29}$ Fabrice LEDUC, "Causalité civile et imputation, en Les distorsions du lien de causalité en droit de la responsabilité civile”, dans Actes du Colloque des 15 et 16 décembre 2006, Faculté de Droit et de Science Politique de Rennes, Supplement spécial, Revue Lamy Droit Civil, No 7, Paris, 2007, p. 40 et ss.; Jérôme Fischer, "Causalité, imputation, imputabilité: Les liens de la responsabilité civile”, dans oeuvrage collectif, Libre Droit. Mélanges en l'honneur de Philippe le Tourneau, París, Dalloz, 2008, p. 383 et ss., Fernando Pantaleón Prieto, "Causalidad e imputación: criterios de imputación”, en Centenario del Código Civil, Madrid, Asociación de Profesores de Derecho Civil, Centro de Estudios Ramón Arces, 1990, tomo II, p. 1.561 y ss. 
5. d) La ausencia de un criterio coherente de apreciación

A decir verdad, no existe (tanto en doctrina como en jurisprudencia) un criterio uniforme de aprehensión del vínculo de causalidad (en su función de requisito autónomo de la responsabilidad civil). En ocasiones, disfrazada de certeza, se le da el papel de "cortapisa" insalvable en virtud del cual podrá ser rechazado, sin más, el reclamo indemnizatorio. Otras veces, muy por el contrario, el análisis causal podrá pasar por inadvertido, teniéndose por constatada sobre la base de meras conjeturas o, cuando no, suplantada, deformada o absorbida por otros elementos de la fattispecie (como la culpa $^{30}$ o el daño $\left.{ }^{31}\right)$.

5. e) La identidad de tratamiento del análisis causal en ambas égidas de la responsabilidad civil (contractual y delictual)

Al mismo tiempo, jueces y doctrinos resuelven de la misma forma el problema del nexo causal, tanto en un caso de responsabilidad contractual como en otro de responsabilidad delictual. Se hace caso omiso a que, en materia contractual, interesa el juicio de causalidad en el ámbito de extensión del daño resarcible. La imputación del hecho dañoso y la identificación del responsable no dan lugar a problemas porque el sujeto responsable viene identificado a través de la obligación incumplida, con otras palabras, para verificar el an debeatur alcanza con verificar el incumplimiento de la prestación. Para el caso de la responsabilidad extracontractual, por el contrario, para verificar el an debeatur, es necesario realizar una operación más compleja ${ }^{32}$.

Cabe hacer notar, por otra parte que, en buena medida, esta errónea apreciación de la causalidad en el ámbito de autoría se forjó en el entorno de la responsabilidad civil médica (común denominador de los últimos grandes hitos revolucionarios), ya que bien supo ser el banco de pruebas de reconocidas doctrinas foráneas de dudosa adaptación en nuestro entorno jurídico (por ejemplo, pérdida de una chance de curación, causalidad vir-

\footnotetext{
${ }^{30}$ La definición de culpa tiene, entre otros, un "aspecto netamente causalístico". Carlo Maiorca, "Colpa civile", in Enciclopedia del Diritto, Milano, Giuffrè editore, 1960, vol. 7 (Cir - Compa), p. 535; "que se acentúa cuando se la vacía de toda connotación subjetiva”. Vittorino Pietrobon, Illecito e fatto illecito, Padova, Cedam, 1998, p. 75 e ss.; "Es por eso que, no es raro que la relación de causalidad adquiera relevancia jurídica solo si existe culpa". Vinicio Geri, Responsabilità civile per danni da cose ed animali, Milano, Giuffrè editore, 1963, p. 34 e ss.

${ }^{31}$ Tal es la posición de Raymond SALEILLES, Essai d'une théorie générale de l'obligation: d'après le projet de Code Civil allemand, Paris, Librairie F. Pichon successeur, 1890, № 305 p. 360.

${ }^{32}$ Marco CAPECCHI, Il nesso di causalità. Da elemento della fattispecie "fatto illecito" a criterio di limitazione del risarcimento del danno, 2a ed., Padova, Cedam, 2005, p. 23.
} 
tual, comportamiento anormal de las cosas inertes, obligaciones in solidum, etc.), o de fútiles teorías sobre la carga de la prueba (por ejemplo, cargas probatorias dinámicas).

Quizá haya tenido razón Maxime Mignon ${ }^{33}$ y no se haya advertido que es imposible incorporar el ejercicio de la Medicina a la esfera del contrato, sin provocar disonancias y dificultades de adaptación irreductibles. El particularismo de la relación médico-paciente es tal que hace poco factible aplicarle la mayoría de los mecanismos contractuales ordinarios. De hecho, muchos de los remedios ideados para el régimen contractual, se vuelven inverosímiles en materia de responsabilidad médica (por ejemplo, facultad de exigir el equivalente pecuniario de la prestación, limitación consecuencial del daño, carácter simplemente mancomunado de la obligación resarcitoria, facultad de exigir el cumplimiento in natura de la prestación sea ya, por el propio deudor o por un tercero a su costa, etcétera).

5. f) La identidad de tratamiento del análisis causal tanto para supuestos de responsabilidad subjetiva como de responsabilidad objetiva

También es poco habitual que a la hora de constatar el presupuesto causal no se distinga si se está frente a un caso de responsabilidad objetiva o ante 150 uno de índole subjetiva. Sabido es que, pues, en la primera categoría, la noción de causa jurídicamente relevante pierde parte de su significado tradicional y cobra un especial relieve o, lo que es igual, adquiere una "configuración diferente". Dicho de otra forma, varía el "asiento" sobre el cual se edifica la indagación retrospectiva, ya que en un sistema objetivo de responsabilidad, la imputación del daño al agente se desvincula de todo ropaje de subjetividad y cabe atribuirlo al responsable, no porque se haya conducido en forma negligente, sino porque el resultado del hecho dañoso sobreviene a consecuencia de un evento ocurrido en el ámbito de aplicación de una norma especial.

En efecto, el nexo de causalidad es un elemento fundamental en la relación de responsabilidad, tanto en el campo de la responsabilidad objetiva como en el de la responsabilidad subjetiva. Lo que ocurre es que en este último caso, la relación de causa a efecto entre el comportamiento culpable del agente y el evento nocivo es más evidente, lógica y directa, mientras que en el segundo, esa relación se da entre la situación regulada por la ley especial (situación, actividad, etc.) y ese evento ${ }^{34}$.

${ }^{33}$ Maxime Mignon, "Le fondement juridique de la responsabilité civile des médecins et chirurgiens", in Dalloz, No II, Paris, 1950, p. 121.

${ }^{34}$ Emilio VALSECCHI, "Responsabilità oggettiva aquiliana e caso fortuito", in Rivista di Diritto Commerciale, No I, Padova, 1947, p. 151 e ss. 
5. g) La ficción de atribuir relevancia causal a las cosas inertes

No menos problemática es la cuestión del nexo causal en aquellos supuestos de daños en que intervienen cosas inertes. Algunos, en contraposición a las leyes de la naturaleza, atribuyen relevancia causal al hecho de la cosa; otros, hacen hincapié en la situación, condición o particular circunstancia prevista por la ley especial y, finalmente, están quienes abordan la cuestión en clave subjetiva, indagando si la causa del daño fue conducta desaprensiva, desidiosa u omisa de quien debía vigilar o custodiar la cosa. Es que en rigor, probar el comportamiento anormal de la cosa no es sino dar cuenta de la conducta desaprensiva, desidotra u omisa (rectius culpable) de quien debía vigilarla o custiodarla, puesto que lo que se analiza, en definitiva, es como la cosa llegó a esa posición o comportamiento anormal ${ }^{35}$.

5. h) La teoría del "todo o nada" y la regla de la "indivisibilidad de la causa del daño"

Durante largo tiempo se exigió que el daño sea corolario ineluctable, directo y único de la conducta del sujeto endilgado responsable ${ }^{36}$. Si bien con el transcurso del tiempo el Derecho suavizó paulatinamente esta exigencia, aún perduran resabios de la misma como, por ejemplo, la formula optativa del "todo o nada".

Este vetusto modo de razonar se asienta sobre dos pilares fundamentales:

1) la regla de la "indivisibilidad de la causa del daño" ${ }^{37} \mathrm{y}$

2) la exigencia de que el nexo causal sea demostrado en forma indubitable, es decir, con "certeza absoluta".

Como consecuencia de ello, en todos los casos en que no se logre probar fehacientemente "el cómo y el porqué" del perjuicio sufrido, esto es, mientras no surja con palmaria claridad la relación de causalidad entre la conducta del accionado y el daño reclamado por el pretensor, el reclamo indemnizatorio debe ser rechazado.

${ }^{35}$ Jorge MAYO, "Responsabilidad civil por los daños causados por cosas inertes", en Alberto Bueres (dir.) - Elena Higthon (coord.), Código Civily normas complementarias. Análisis doctrinario y jurisprudencial, Buenos Aires, Hammurabi, 1999, tomo 3A, p. 631; Piaggio (n. 28).

${ }^{36}$ Así, en el Derecho primitivo se exigía que el daño fuera cometido corpore corpori, esto es, no sólo sobre el cuerpo de la víctima sino, también, por el cuerpo del agresor. Olivier Descamps, Les origines de la responsabilité pour faute personnelle dans le Code civil de 1804, Paris, Librairie Générale de Droit et de Jurisprudence, 2005, p. 94 et ss.; David Deroussin, Histoire du Droit des obligations, Paris, Economica, 2007, p. 686, Jean-Louis GazzAniga, Introduction historique au Droit des obligations, Paris, Presses Universitaires de France, 1992, p. 220.

${ }^{37}$ Sobre el principio de indivisibilidad, véase Chabas (n. 25), pp. 4, 9 y ss. y Marc Mignot, "Les obligations solidaires et les obligations in solidum", in Droit privé français, Paris, Dalloz, 2002, p. 225 et ss. 
Así las cosas, la exigencia de tener que probar en forma fehaciente el nexo causal, además de ser revisada y, en buena parte, suplantada por una orientación causal de corte "probabilística" 38 , fue el caldo de cultivo para el nacimiento de dos categorías por lo demás controvertidas: las obligaciones in solidum y la pérdida de una chance de curación o supervivencia ${ }^{39}$.

5. i) La escasez de trabajos monográficos o investigaciones jurídicas (de índole civil) al respecto

El análisis del nexo causal ha recibido escasísima atención en comparación al resto de los elementos de la responsabilidad, a decir verdad, son muy pocos los autores que se han ocupado del tema. Así, entre las contribuciones más destacadas (recientes o de antigua data), cuadra traer a colación las monografías de Paolo Forchielli ${ }^{40}$, Francesco Realmonte ${ }^{41}$, Pietro Trimarchi $^{42}$, Giovanna Visintini ${ }^{43}$, Carlo Rossello ${ }^{44}$, Marco Capecchi ${ }^{45}$ y Roberto Pucella $^{46}$ (en Italia); Robert Guex ${ }^{47}$ (en Suiza), Patrice Marteau ${ }^{48}$, Joseph Favier $^{49}$, François Chabas ${ }^{50}$, Cédric Beaudeux ${ }^{51}$ y Cristophe Quezel-Ambrunaz $^{52}$ (en Francia); Jean-Luc Fagnart ${ }^{53}$ (en Bélgica); Herbert Hart-Tony

${ }^{38}$ Una vez abandonado su perfil newtoniano, la causalidad se rediseñó en términos de probabilidad. Miguel-Federico de Lorenzo, El daño y las causas de justificación. A propósito del Proyecto de Código Civil de 1998, Madrid, La Ley, 2000-C, p. 975).

${ }^{39}$ Lina Williatte-Pelutteri, Contribution à l'élaboration d'un Droit civil des événements aléatoires dommageables, Paris, Librairie Générale de Droit et de Jurisprudence, 2009, p. 198, BÉnABent, Alain, La chance et le Droit, Paris, Librairie Générale de Droit et de Jurisprudence, 1973, p. 200.

${ }^{40}$ Paolo Forchielui, Il rapporto di causalità nell'illecito civile, Cedam, Padova, 1960.

${ }^{41}$ Realmonte (n. 18).

${ }^{42}$ Pietro Trimarchi, Causalità e danno, Milano, Giuffrè editore, 1967.

${ }^{43}$ Giovanna Visintini (a cura di), Ifatti illeciti, Padova, Cedam, 1999, vol. 3: Causalità e danno.

${ }^{44}$ Carlo Rossello, Il danno evitabile, Padova, Cedam, 1990.

${ }^{45}$ CAPecchi (n. 32).

${ }^{46}$ Roberto PuCELla, La causalità incerta Torino, Giappichelli editore, 2007.

${ }^{47}$ Robert Guex, La relation de cause à effet dans les obligations extra-contractuelles, thèse, Lausanne, Université de Lausanne, Imprimerie Charles Pache, 1904.

${ }^{48}$ Patrice Marteau, La notion de causalité dans la responsabilité civile, thèse, Aix-enProvence, Aix, 1913.

${ }^{49}$ Joseph FAVIER, La relation de cause à effet dans la responsabilité quasi délictuelle, thèse, Paris, 1951.

${ }^{50}$ Chabas (n. 25).

${ }^{51}$ Cédric Beaudeux, Causalité, fondement pour une theorie générale de la responsabilité civile, thesè, Strasbourg, Université Robert Schuman de Strasbourg III, 2006.

${ }^{52}$ Christophe Quezel-Ambrunaz, Essai sur la causalité en Droit de la responsabilité civile, Paris, L.G.D.J., 2010.

${ }^{53}$ Jean-Luc FAGnart, La causalité, Belgium, Kluwer, 2009. 
Honoré $^{54}$ (en Inglaterra), Ramón Domínguez Águila ${ }^{55}$ y Fernando Araya Jasma $^{56}$ (en Chile) e Isidoro Goldenberg ${ }^{57}$, Roberto Brebbia ${ }^{58}$, Osvaldo Paludi ${ }^{59}$ y Hugo Acciarri ${ }^{60}$ (en Argentina).

Es de destacar, no obstante, y en lo que al Derecho Civil chileno compete, los sendos aportes de Arturo Alessandri Rodríguez (De la responsabilidad extracontractual en el Derecho civil chileno. Título 35 del Libro IV del Código Civil, Santiago, Imprenta Universitaria, 1943, pp. 238 a 251); Jorge Baraona ("La causa del daño en la jurisprudencia reciente", en Revista Chilena de Derecho, vol. 30, No 2, Santiago, mayo-agosto, 2003, pp. 345 a 379 y "La cuestión causal en la responsabilidad civil extracontractual: panorama de derecho comparado", en Revista Chilena de Derecho, vol. 31, No 2, Santiago, 2004, pp. 211 a 223); Hernán Corral Talciani ("La relación de causalidad en el sistema de torts del Common Law", en María Dora Martinic-Galetovic (coord.), Nuevas tendencias del Derecho, Santiago, LexisNexis, 2004, pp. 141 a 162); Enrique Barros Bourie (Tratado de responsabilidad extracontractual, Santiago, Editorial Jurídica de Chile, 2009, pp. 373 a 444; Cristián Aedo Barrena (Responsabilidad extracontractual, Santiago, Librotecnia, 2006, p. 271 a 308).

5. j) El tomar y aplicar, sin más, los criterios elaborados por los cultores del Derecho Penal

Bien señala Vincenzo Zeno-Zencocich que trasladar al ámbito civil el modelo causal defendido por la doctrina penal ha oscurecido la cuestión en vez de aclararla ${ }^{61}$. Debe observarse, ante todo, que la lógica que gobierna el ilícito penal es muy distinta a aquélla que preside a la responsabilidad civil. Una primera razón, de tipo estructural, radica en que la concepción moderna del Derecho de Daños construye su esquema en derredor del hecho dañoso, a diferencia del Derecho Penal, que lo hace en función de la

\footnotetext{
${ }^{54}$ Herbert Hart, Tony Honoré, Causation in the Lare, Oxford, Clarendon Press, 1985.

${ }^{55}$ Ramón Domínguez Águila, La causalité dans la responsabilité en Droit comparé francais et chilien, thesè, Toulousse, Université de Toulousse, 1967.

${ }^{56}$ Fernando Araya Jasma, La relación de causalidad en la responsabilidad civil, Santiago, LexisNexis, 2003.

${ }^{57}$ Isidoro Goldenberg, La relación de causalidad en la responsabilidad civil, Buenos Aires, La Ley, 2000.

${ }^{58}$ Roberto Brebia, La relación de causalidad en el derecho civil, Rosario, Juris, 1975.

${ }^{59}$ Osvaldo Paludi, La relación de causalidad en la responsabilidad civil por el hecho propio, Buenos Aires, Astrea, 1976.

${ }^{60}$ Hugo AcCIARri, La relación de causalidad y las funciones del Derecho de daños. Reparación, prevención, minimización de costos sociales, Buenos Aires, Abeledo Perrot, 2009.

${ }^{61}$ Vincenzo Zeno-Zencovich, La responsabilità civile da reato. Lineamenti e prospettive di un sottosistema giurisprudenziale, Padova, Cedam, 1989, p. 39 e ss.
} 
conducta ilícita del delincuente ${ }^{62}$. La segunda razón, de orden normativofuncional, reside en que la noción civilista de causalidad busca el nexo con el daño tanto en el an como en el quantum respondeatur ${ }^{63}$, y no sólo en el an debeatur, de cara a la aplicación de la pena, como acontece en el Derecho Penal ${ }^{64}$. Por lo que el problema de la causalidad es mucho más vasto en el Derecho la responsabilidad civil que en el fuero penal.

Esto no quita que puedan "adoptarse" con provecho algunas de las nociones, tesis, razonamientos o conclusiones que, fruto de enjundiosos estudios, allegasen los investigadores del Derecho Criminal (Francesco Antolisei, Giuseppe Bettiol, Federico Stella, Salvatore Aleo, Günther Jakobs, Claus Roxin, etc.), siempre y cuando, claro está, se las "adapte" a las normas, estructura y función de la responsabilidad civil.

\section{5. k) La causalidad: una noción flexible y multiforme}

Para preservar su papel de requisito basal de la responsabilidad civil, la causalidad debió mutar bajo "múltiples formas", acordes a la esfera o fattispecie en la que interactúa (v.gr.: responsabilidad objetiva, subjetiva, contractual, delictual, por hecho propio, por hecho ajeno, por hecho de las cosas, etcétera).

154 5. 1) La causalidad: una noción incierta.

No pocas veces sucede que, ante determinados sucesos, es muy difícil, cuando no imposible, establecer cuál o cuáles han sido las causas relevantes, a los efectos jurídicos, para producir el menoscabo. De ahí, pues, que la exigencia tradicional de un vínculo causal directo, ha quedado reducida sólo para simples acontecimientos ${ }^{65}$, y no para casos complejos (que son, prácticamente, la gran mayoría), donde la aprehensión del elemento causal se ha, lisa y llanamente, "flexibilizado". Sin ánimo de exhaustividad, pueden mencionarse los siguientes supuestos:

${ }^{62}$ Guido Alpa, Trattato di Diritto civile, Milano, Giuffrè editore, 1999, tomo IV: La responsabilità civile, p. 318; Vincenzo CARBONE, Il fatto dannoso nella responsabilità civile, Napoli, Jovene, 1969, p. 317, SALVI (n. 8), p. 169 e ss.

63 "La polivalencia del término daño y el debate suscitado en torno a la causalidad jurídica son de por sí extraños a la problemática penalista". Cesare SAlvi, Il danno extracontrattuale. Modelli e funzioni, Napoli, Jovene, 1985, p. 48, "donde las consecuencias ulteriores al delito no revisten trascendencia; puesto que guardan con el evento una simple relación de mera accidentalidad", ForChiELLI (n. 40), p. 24.

${ }^{64}$ Giovanni Valcavi, "In torno al rapporto di causalità nel torto civile”, in Rivista di Diritto Civile, No II, Padova, 1995, p. 481 e ss.

${ }^{65}$ Catherine Thibierge, "Libres propos sur l'evolution du Droit de la responsabilité (vers un élargissement de la fonction de la responsabilité civile?)”, dans RTDciv., $\mathrm{N}^{\circ} 3$, Paris, 1999, p. 561. 


\subsection{Casos de causalidad concurrente}

Negar que tanto la propia víctima como un tercero o, incluso, el fortuito, pueden interferir a título de concausa con el hecho imputado al demandado en la producción del resultado dañoso y, por consiguiente, repartir la responsabilidad en proporción a la incidencia causal que la conducta de cada uno tuvo en el acaecimiento del evento lesivo, trajo entre otras consecuencias, las obligaciones in solidum y la pérdida de una chance de curación o supervivencia.

\subsubsection{Pérdida de una chance de curación o supervivencia}

La pérdida de una chance de curación representa un problema de índole causal o es, más precisamente, un caso de causalidad concurrente ${ }^{66}$ (donde tanto las predisposiciones del paciente ${ }^{67}$ como la falta del médico, inciden en la producción del resultado final nocivo). Por ende, nada más sencillo que indemnizar al damnificado a título de chance, esto es, bajo una suerte de (incomprensible) perjuicio intermedio ${ }^{68}$.

Ignorada la noción de daño "final" (muerte, lesiones o incapacidad), el obstáculo causal (en su concepción tradicional) lisa y llanamente se desvanece y es, en consecuencia, reemplazado por un nuevo nexo causal (aunque virtual) que ahora enlaza la conducta culpable del galeno con la pérdida de probabilidades de evitar un resultado nocivo.

En suma, se trata de un artificio instrumental a través del cual el juez (quizá abarrotado de expedientes), lejos de tener que indagar causalmente la cuestión, opta (aunque no siempre en beneficio de la víctima), por indemnizar parcialmente (léase a ojo), los detrimentos irrogados por la acción u omisión culposa del profesional que no sabe certeramente (¿̇y la probabilidad?) qué incidencia causal tuvo en el desenlace final nocivo.

Tal es así que los jueces, ha desnudado magistralmente René Savatier,

"utilizan este procedimiento cuando no están seguros de la relación causal entre la muerte -o lesiones- y la culpa del médico (...). La

${ }^{66}$ Vincenzo Zeno-Zencovich, La sorte del paziente, Padova, Cedam, 1994, p. 100; Valèrie TACChini-LAforest, "Reflexion à propos de la perte d' une chance", in Petites Affiches, $\mathrm{N}^{\circ} 20$, Paris, 19 Julliet, 1999, p. 9 et ss.

${ }^{67}$ Con respecto a la influencia de las predisposiciones de la víctima sobre la pretensión resarcitoria, véase Jacqueline, NGuyen Thanh Nha, "Linfluence des prédispositions de la victime sur l'obligation á reparation du défendeur á l'action en responsabilité", in RTD civ., No 75, Paris, 1976, p. 1 et ss.; Dominique Thouvenin, La responsabilité médicale, Paris, Médecine-Sciences Flammarion, 1995, p. 42.

${ }^{68}$ Jean Penneau, La responsabilité du medicin, Paris, Dalloz-Sirey, 1992, p. 34. 
misión del juez es juzgar y no dosificar sus dudas (...). La teoría de la chance de supervivencia consagra el paraíso de los jueces indecisos" ${ }^{\prime 69}$.

De ahí que, agrega Rafaella de Matteis,

"esta doctrina asume un significado tremendamente ambiguo, pudiendo ser utilizada tanto para condenar a resarcir a un médico que, a la postre, no causo el daño; como para absolverlo de aquel detrimento que sí ocasionó" 70 .

Boris Starck lo resume de manera inobjetable:

"la pérdida de una chance es un instrumento de equidad que permite tener un gesto a favor de la víctima, toda vez que la incertidumbre sobre el nexo causal prohíbe una reparación integral"71.

\subsubsection{Obligaciones in solidum}

Se trata de otra creación pretoriana de la doctrina judicial gala, que consiste en una fórmula de vinculación solidaria que no sólo refuerce la tutela

156 del damnificado sino, también, que permita salvar la ausencia de norma expresa y, por ende, la consiguiente presunción de mancomunación que rige (a título de presunción), las obligaciones con pluralidad de sujetos pasivos $^{72}$. Tal es así, que esta peculiar y extravagante construcción nace con independencia de toda disposición legal ${ }^{73} \mathrm{o}$, más precisamente, en palmaria contraposición a la ley ${ }^{74}$.

No es un dato menor que este ingenioso subterfugio se haya gestado en el Derecho francés, cuyo Code adolece de una previsión legal que ubique a los actos ilícitos entre los supuestos de "solidaridad legal"75 (como sí ocurre,

${ }^{69}$ René Savatier, "Une faute peut'elle engendrer la responsabilité d'un dommage sans l'avoir causée?, dans Dalloz, No 2, Paris, 1970, p. 126.

${ }^{70}$ Raffaella de Matteis, La responsabilitá medica, Padova, Cedam, 1996, p. 476 e ss.

${ }^{71}$ Starck, Roland, Boyer (n. 11), p. 64.

${ }^{72}$ Mariano YzQuierdo Tolsada, Sistema de responsabilidad civil, contractualy extracontractual, Madrid, Paris, Dykinson, 2001.

${ }^{73}$ Jean VincEnt, "L'extension en jurisprudence de la notion de solidarité passive", dans RTDciv., $\mathrm{N}^{\circ} 4$, Paris, 1939, p. 601 et ss.

${ }^{74}$ Auguste-Jean-Batiste Sourdat, Traité général de la responsabilité ou de l'action en dommagesintérêts en dehors des contrats, avec la collaboration de Louis Sourdat, $5^{\mathrm{a}}$ éd. revue et augmentée, Paris, Marchal \& Billard, 1902, volume 1, p. 68.

${ }^{75}$ En un contexto donde la causalidad parcial no tiene cabida ("indivisibilidad de la causa del daño"), y en el cual la relación causal debe ser probada en forma indubitable ("todo o nada"), esta figura no es más que un artificio tendiente a desvirtuar el principio 
por ejemplo, en el Derecho chileno: arts. 2317 y concordantes del Código Civil, en el Derecho argentino: art. 1109 y concordantes o, en el Derecho uruguayo: art. 1331 y concordantes).

Por otra parte, no es un dato menor que en todos los ordenamientos jurídicos en los que se aplica (entre ellos, Chile, Argentina, Uruguay, etc.), la noción de obligación in solidum no es clara ni uniforme, especialmente en lo que respecta a su "autonomía" (¿tercer género?, ¿'solidaridad judicial?, ¿categoría de solidaridad?); "naturaleza" (pena privada, garantía del acreedor, carga del deudor, etc.); "nomen iuris" (obligaciones concurrentes, conexas, indistintas, convergentes, etc.); "legalidad" (‘ contra legem?) y "régimen aplicable” (ámbito, efectos, etcétera).

\subsection{Casos de cursos causales no verificables}

Muchas veces se produce un daño a múltiples personas que, anteriormente, han tenido la misma relación con un factor determinado, pero se desconoce exactamente cuál es el mecanismo y el proceso productor del menoscabo. Así por ejemplo, los resonantes casos del aceite de colza ${ }^{76}$; la talidomida ${ }^{77}$; el amianto ${ }^{78}$; el tabaco ${ }^{79}$; el $\mathrm{PCB}^{80}$; el wrongful conception (anticoncepción fallida que tiene como resultado el nacimiento de un bebe sano), wrongful birth y wrongful life (nacimiento de un niño con deformaciones o taras que

de mancomunación simple sentado por el art. 1202 y concordantes del Código Napoleónico. Maurizio de Acutıs, "La solidarità nella responsabilità civile", in Rivista di Diritto Civile, vol. II, Padova, 1975, p. 531.

${ }^{76}$ La mayor indemnización civil concedida en España por el envenenamiento masivo de personas con "aceite de colza desnaturalizado", fue concedida al margen de la relación de causalidad. Álvaro Luna Yerga, La prueba de la responsabilidad civil médico-sanitaria. Culpa y causalidad, Madrid, Civitas, 2004, p. 354.

${ }^{77}$ La talidomina era un fármaco utilizado masivamente como sedante para embarazadas, entre los años 1858 y 1962, que producía efectos genotóxicos hasta por aquel entonces desconocidos, en virtud de los cuales nacieron miles de niños con toda clase de deformidades físicas. Al respecto, véase Federico STELLA, Leggi scientifiche e spiegazione causale nel Diritto penale, $2^{\mathrm{a}}$ ed., Milano, Giuffrè editore, 2000, p. 122 e ss.

${ }^{78}$ Se han registrado varios casos de asbestosis, cáncer y mesotelioma tanto de pleura como de peritoneo, en personas que, por lo general, han inhalado amianto o, si se prefiere, asbesto. Alessandro Marinaccio, "Esposizione ad amianto ed insorgenza di casi di mesotelioma maligno. Evidenze epidemiologiche e causalità", in Roberto PUCELLA, Giovanni de SAntis, Il nesso di causalità. Profili giuridici e scientifici, Padova, Cedam, 2007, p. 113 e ss.

${ }^{79}$ Giulio PonZANeLLI, "I problema della tutela risarcitoria da fumo attivo", in Responsabilità Civile e Previdenza, No 4-5, Milano, Giuffrè editore, 2005, p. 964 e ss.

${ }^{80}$ También el uso de PCB en ámbitos laborales, en transformadores de energía eléctrica o, en residuos peligros, ha generado (amén del dictado de normas específicas que regulan su uso), importantes investigaciones que, a la postre de la difusión de múltiples casos con idéntico patrón, lo han calificado como un probable factor cancerígeno. 
habrían podido ser detectadas durante el embarazo $)^{81}$ o de ciertos virus que al propagarse (por el aire, a través de vectores, mediante alimentos, materia fecal, contacto físico o sexual), provocan enfermedades (por ejemplo, hepatitis, síndrome de inmunodeficiencia adquirida, infecciones hospitalarias, etcétera ${ }^{82}$.

\subsection{Casos de cursos causales hipotéticos}

En otras ocasiones, el hecho dañoso es efectivamente desencadenado por la conducta del agente, frente al cual se pretende establecer la obligación de indemnizar; pero se demuestra que el daño igualmente se hubiese producido sobre la base de un evento natural o en función de la conducta de un tercero, que daría lugar a su responsabilidad ${ }^{83}$.

\subsection{Casos de cursos causales omisivos}

En sentido filosófico la causa sólo es relevante cuando estamos frente a una acción. La conducta inerte carece de toda eficacia causal, porque es un no hacer, un quid vacui. De allí entonces, una serie de casos tales como:

\subsubsection{Omisión de informar adecuadamente} al paciente

Un supuesto peculiar se plantea en aquellos casos donde el médico omite informar adecuadamente al paciente. Veamos las siguientes hipótesis:

1) el paciente, de haber recibido la información adecuada, habría optado por el tratamiento o intervención;

2) el paciente, de haber recibido la información adecuada, habría optado por la no operación o terapia, no obstante que a la postre se ejecute de manera diligente $y$, por último,

3) el paciente, no recibió la información adecuada y la intervención se ejecutó, aunque en forma negligente.

${ }^{81}$ Joaquín Ataz LÓPEz, "Las wrongful actions en material de responsabilidad médica", en Antonio Orti Vallejo(dir.), María Carmen García Garnica (coord.), La responsabilidad civil por daños causados por servicios defectuosos, Navarra, Thomson-Aranzadi, 2006, p. 341 y ss.

${ }^{82}$ Ampliar en Daniel Mainguy, "Le traitement juridique des infections nosocomiales", en Antoine LeCA et François Vialda, Le risque épidémique. Droit, histoire, médicine et pharmacie, Aix-en-Provence Marseille, Presses Universitaires d'Aix-Marseille, 2003, p. 344 et ss.; Daphné Tapinos, Prévention, précaution et responsabilité civile. Risques avéré, risqué suspecté et transformation du paradigme de la responsabilité civile, Paris, Harmattan, 2008, p. 173 et ss.

${ }^{83}$ Francisco Infante Ruiz, La responsabilidad por daños. Nexo de causalidad y causas hipotéticas, Valencia, Tirant Lo Blanch, 2002, p. 17 y ss.; Trimarchi (n. 42), p. 165 e ss.; Martín García-Ripoll Montijano, Imputación objetiva, causa próxima y alcance de los daños indemnizables, Granada, Comares, 2008, p. 68 y ss. 
Sin embargo, es sólo en la segunda hipótesis, donde se han generado sendas discordancias respecto al presupuesto causal, proponiéndose un abanico de posibilidades solutivas, tales como, recurrir (so color de resarcir, claro está) a la teoría de la equivalencia de condiciones, cuando no al artilugio de la pérdida de una chance de curación o supervivencia o, más modernamente, a la doctrina de la imputación objetiva.

\subsubsection{Omisión de mitigar las consecuencias nocivas del menoscabo}

Otro tema que ha sabido concitar contrastes de opinión es el que compete al deber de minimizar el daño. Una primera tesitura sostiene que se trata de un problema causal que, por ende, cabe incardinar en el an debeatur. Otros, por el contrario, ubican la cuestión en la esfera del quantum respondeatur puesto que, de admitirse un deber de mitigar el daño impuesto a la víctima, éste sólo puede nacer una vez que el daño se ha causado.

\subsubsection{Omisión de organizar y coordinar}

la prestación del servicio de salud

La Medicina actual, ejercida en grandes centros u organizaciones hospitalarias, determina que muchas veces resulte difícil, cuando no imposible, identificar con precisión al sujeto -o sujetos- concreto responsable de un acto sanitario que causó o contribuyó a causar el menoscabo.

De ahí que, ante la existencia de deficiencias no se requiera la individualización concreta del facultativo o facultativos causantes del daño para declarar la responsabilidad del ente asistencial, público o privado, prestador de la atención médica inadecuada. Va de suyo que si la estructura sanitaria tiene la obligación de organizar y coordinar los medios necesarios para prestar el servicio de salud, será responsable de los daños que su organización deficitaria acarree ${ }^{84}$.

\subsection{Casos de daños causados por un sujeto no identificado} que forma parte de un grupo de personas

Puede suceder que la autoría de la conducta lesiva, y con ello la constatación del nexo causal, se diluyan entre la pluralidad de personas que integran un

\footnotetext{
${ }^{84}$ Una buena organización hospitalaria requiere poner a disposición del paciente personal calificado, en número suficiente y presente en los momentos necesarios, desempeñar una actividad coordinada en los diferentes servicios, utilizar productos seguros y sanos, mantener sus instalaciones en forma higiénica, etc. François CHABAS, "La responsabilità delle strutture sanitarie per difetto di organizzazione. Studio di diritto privato francese", in Responsabilità Civile e Previdenza, N $^{\circ}$ 1, Milano, 2001, p. 13 et ss.; Raffaella de MatTeIs, Responsabilità e servizi sanitari. Modelli e funzioni, Padova, Cedam, 2009, p. 56 e s.; Roberto Simone, "La responsabilità della struttura sanitaria pubblica e privata", in Danno e Responsabilità, $\mathrm{N}^{\circ} 1$, Milano, Ipsoa Editore, 2003, pp. 9, 12.
} 
mismo grupo. Se trata del típico caso de daños causados por un sujeto no identificado que forma parte de un grupo de personas ${ }^{85}$.

\section{§ II. TEORÍAS SOBRE LA RELACIÓN DE CAUSALIDAD}

\section{Teorías causales de inspiración filosófica. Críticas}

a) La equivalencia de condiciones. Remisión acápite

$\S$ IV, punto 1 a)

b) La causa próxima

Esta teoría erige al título de causa sólo a la condición que está más próxima, inmediata o es anterior al resultado. Únicamente las condiciones más cercanas en tiempo y espacio son las determinantes del menoscabo.

Si bien no puede negarse que su aplicación permite no extender de manera desmesurada, en el tiempo y en el espacio, la influencia causal de los diversos factores, este criterio jurídico (basado en el tiempo) ha sido objeto de aquilatadas críticas, cuyo desarrollo excede con creces el marco de este breve ensayo. Sólo cabe agregar que su mayor debilidad está en que coloca todo el énfasis en el factor física o mecánicamente más cercano y omite demostrar lo único que realmente interesa: que ese antecedente más cercano es la causa del evento, lo que impide solucionar de forma debida los casos en que el evento se produce por varias causas (concausas): la causa última no tiene porqué ser necesariamente la causa dominante y eficiente $^{86}$.

\section{Teorías causales de inspiración científica. Críticas}

\section{a) La condición preponderante o causa eficiente}

La teoría de la condición preponderante o de la causa eficiente, al igual que la de la causa próxima, son teorías individualizadoras, porque buscan, mediante la elección de una causa, superar los problemas que surgen de las dos anteriores. La condición preponderante es

${ }^{85} \mathrm{Al}$ respecto, véase Ilhan Postacioglu, "Les faits simultanes et le probleme de la responsabilité collective", dans RTDciv., No 3, Paris, 1954, p. 438 et ss.; Hassen AbERKANe, "Du dommage causé par une personne indeterminée dans un groupe", dans RTDciv., spècial No 29, Paris, 1958, p. 516 et ss.; Stathis BANAKAs, "Causalité juridique et imputation: réflexions sur quelques développements récents en Droit anglais", in Revue Lamy Droit Civil, No 40 , Paris, 2007 , p. 97 et ss.

${ }^{86}$ Carlos Calvo Costa, Derecho de las obligaciones, Buenos Aires, Hammurabi, 2010, tomo 2: Derecho de daños, p. 260. 
"aquella condición que rompe el equilibrio entre los factores favorables y contrarios a la producción del daño, influyendo decisivamente en el resultado".

La causa eficiente, a diferencia de la equivalencia de condiciones, sostiene que no todas las causas son iguales, sino que algunas son más eficientes que otras para producir un resultado. Para saber cuándo una causa es más eficiente que otra se utilizaron dos criterios:

a) Uno cuantitativo, que sostiene que es más eficiente aquella que en mayor medida o con mayor fuerza ha contribuido al resultado.

b) Otro cualitativo, que afirma que lo decisivo es la mayor o menor eficacia interna en el proceso causal, según el curso normal de los sucesos.

La crítica que se formula a esta teoría, es que a veces es imposible separar, escindir, una causa de otra, o que es muy difícil determinar, cuál es la más eficiente, cuando concurren varias causas ${ }^{87}$.

b) La causa adecuada

Según esta teoría, para imponer a alguien la obligación de reparar el daño sufrido por otro, no basta que el hecho haya sido, en el caso concreto, conditio sine qua non del daño, sino que es necesario, además, que, en virtud de un juicio (hipotético-retrospectivo) de probabilidad, basado en las máximas de la experiencia, resulte una causa adecuada para ello.

Sin perjuicio del gran predicamento adquirido, a punto tal que, en la actualidad, se la considera la posición dominante en la doctrina comparada, tanto en el campo penal como en el civil; la doctrina de la adecuación causal nunca logró alejar de sí la sospecha de mezclar indiscriminadamente causalidad y culpabilidad $^{88}$. Veamos:

b)1. La identificación de la culpa objetiva con la causa adecuada

Sabido es que culpa y causa son, por lo menos en teoría, dos presupuestos distintos y autónomos de la responsabilidad civil. La culpa es, ante todo, factor de atribución, además de eximente, metro de cuantificación y fundamento de atracción causal. La relación de causalidad es, en cambio, un paso previo que busca imputar materialmente el daño a un sujeto.

${ }^{87}$ Edgardo López Herrera, Teoría general de la responsabilidad civil, Buenos Aires, LexisNexis, 2006, p. 202.

${ }^{88}$ Aníbal Piaggio, “Azar y certeza en el Derecho de Daños”, en El Derecho, vol. 152, Buenos Aires,1993, pp. 152-797. 
Por otra parte, a diferencia de otrora, la culpa ha sido despojada de todo componente sicológico, ético o moral, concibiéndosela en términos netamente objetivos; en cuanto a la causa, se ha receptado (casi sin paliativos) la teoría de la adecuación. Sin embargo, he aquí que cuando nos aprestamos a constatar la presencia de estos dos elementos esenciales de la responsabilidad, advertimos que los procedimientos de indagación que se utilizan al efecto, léase: la prognosis póstuma y el juicio de culpabilidad, se entremezclan a punto tal ${ }^{89}$ de volver abstrusas las pretendidas distinciones (lógico-formales) que se suelen circunscribir en derredor de la ambivalente noción de previsibilidad.

En otras palabras, el juicio de culpabilidad (aprehendido en clave objetiva) se confunde con el juicio de causalidad (cuando se la escruta bajo los cánones de la adecuación) o, lo que es igual: culpa objetiva $=$ causa adecudada ${ }^{90}$.

\section{b) 2. Efectos de la confusión}

Las consecuencias de esta superfetación no son menores; así, pues, cuando la responsabilidad se imputa a título subjetivo, el examen sobre la culpabilidad del agente se vuelve una reiteración innecesaria del juicio causal.

La existencia de identidad entre los conceptos de culpa con el de causa, o superposición de ambos, es sumamente preocupante. Significa, ni más ni me-

162 nos, efectuar una doble verbalización, realizar discursos tautológicos. La causa - definida desde la previsibilidad, condición adecuada, humana, etc.- repite, reitera, el mismo discurso que el de la culpa apreciada en abstracto ${ }^{91}$.

Podría sostenerse entonces que, uno de los dos presupuestos sobra, molesta o entorpece y, que si debiésemos prescindir de uno, por razones de orden cronológico, correspondería cargar las tintas sobre la culpa (en tanto se indaga luego de la causa). Por lo que, todo supuesto de responsabilidad, inclusive aquellos que se asientan en un factor subjetivo de atribución, devendrían inexorablemente en objetiva.

En oposición, cuando la responsabilidad se imputa a título objetivo, la única forma de pertenecer fiel a esa nota esencial de objetividad, sería analizar la temática causal desde la teoría de la equivalencia de condiciones; en tanto y en cuanto, es la única que garantiza que la culpa -desalojada en sede del factor de atribución de responsabilidad- no se cuele, pertinaz por la claraboya de la relación de causalidad, vía teoría de la adecuación ${ }^{92}$. De

${ }^{89}$ Confunden o sobreponen en la dicción de Francesco AnTolisei, Il rapporto di causalità nel diritto penale, Torino, Giappichelli, 1960, p. 131. "Hay una surte de contaminación de carácter subjetivo del elemento objetivo". CAPECCHI (n. 32), p. 89.

${ }^{90}$ MaYo (n. 28), p. 232; Luigi Corsaro, Tutela del danneggiato e responsabilità civile, Buenos Aires, La Ley, 2005, p. 159 e ss., Pietrobon (n. 30), p. 75.

${ }^{91}$ Carlos Echevesti, La culpa, Buenos Aires, Hammurabi, 1997, p. 143.

${ }^{92}$ Piaggio (n. 28). 
lo contrario, todo supuesto de responsabilidad, aun aquéllos donde se prescinde de la culpa como criterio legal de imputación, se vuelve subjetiva.

b) 3. Culpa objetiva

Como bien se ha señalado, poco o nada queda de la culpa como aquel comportamiento sicológico del que hablaban los juristas de fines del siglo XIX. Su contextura ontológica, lisa y llanamente se ha metamorfoseado. Por culpa, se entiende hoy la infracción no dolosa del modelo de conducta debida $^{93}$. En otras palabras, culpa es la afirmación de que un comportamiento es contrario a un patrón ideal ${ }^{94}$.

Cuando a la culpa se la califica de objetiva, se alude, o a su apreciación in abstracto, lo cual en cierta medida es poco factible, puesto que a pesar de lo que pudiera parecer, no hay una concepción pura o absolutamente objetiva de culpa o, a un sistema tornasolado -a la vez abstracto y concretoque a la hora de confrontar el actuar real del sujeto con el debido -esto es, al conformar un tipo abstracto de comparación, flexible, circunstancial y específico-, no toma en consideración sus especiales características físicas y sicológicas. He allí, a nuestro modo de ver, lo que se entiende hoy día por culpa objetiva.

En suma, que la teoría de la causalidad adecuada nunca logró alejar de sí, por completo, la sospecha de mezclar indiscretamente causalidad y culpabilidad, no es nada nuevo. Se ha intentado despejar las dudas, marcando que el fenómeno de la causalidad tiene con el de la culpabilidad un elemento común: la previsibilidad. La diferencia estaría en que, en el primer caso, la previsibilidad se computa en abstracto, mientras que en el segundo, se valora en concreto.

Sin embargo, como bien enseña Aníbal Piaggio, el intento tropieza con dificultades insalvables puesto que, a tenor del instrumental conceptual que se maneja, ni es tan abstracta la ponderación de la previsibilidad a los efectos de la relación de causalidad, ni tan concreta la apreciación de la culpa, con lo que el espacio que queda entre ambas órbitas se torna prácticamente imperceptible ${ }^{95}$.

Así, pues, en mayor o menor medida, cuando acometemos la tarea de confrontar, vía hipotética, si tal o cual acción u omisión tiene entidad suficiente, conforme lo que acostumbra a suceder según el curso normal de las cosas, para erigirse en causa adecuada del resultado nocivo, cualquiera sea la posición en la que nos enrolemos (Johannes von Kries, August Thon,

${ }^{93}$ Pier-Giuseppe Monateri, Trattato di diritto civile. Le fonti della obbligazioni, Torino, Utet, 1998, vol. 3: La responsabilità civile, p. 75.

${ }^{94}$ Paolo Forchielli, Responsabilità civile. Lezioni, Padova, Cedam, 1968, p. 75.

${ }^{95}$ Piaggio (n. 28). 
Ludwig Traeger o Robert Hippel), no obstante la sensación objetivista que dicho método de retrospección pueda producir, su descenso a las circunstancias que el sujeto conoció, pudo o debió conocer, resultan una inadmisible recurrencia a una preocupaciones subjetivistas familiares a la temática de la culpa ${ }^{96}$.

Quizá los binomios [culpa objetiva - conditio sine qua non] o [culpa subjetiva - causa adecuada], resulten más coherentes (por compatibilidad) que, el hasta ahora empleado [culpa objetiva - causa adecuada].

\section{§ III. CAUSALIDAD E IMPUTACIÓN}

\section{La causa del daño.}

Nexo causal e imputación objetiva

a) La equivalencia de condiciones. Excesos y defectos

Esta teoría, en cuanto procura mediante el heurístico método de eliminación mental ${ }^{97}$ elevar al rango de causa todos los hechos antecedentes, sin los cuales no se habría producido el evento, no sólo extiende la responsabilidad de manera ilimitada ${ }^{98}$, llegando a resultados absurdos e

164 irrisorios sino que, también, muestra ciertas displicencias en los siguientes supuestos:

1. Casos de causas hipotéticas y causas concurrentes. Ambos grupos tienen en común la particularidad de que, eliminando mentalmente la condición en examen, se observa que el resultado se hubiera producido igualmente; en los casos de causalidad alternativa, por consecuencia de la ulterior actuación de la causa de reserva que no llegó a ser efectiva y, en los casos de causas concurrentes, en virtud de la causa simultánea que, por sí sola, bastaba para producir el daño.

2. Casos de cursos causales no verificables. Años atrás sucedió que muchos enfermos transfundidos resultaron ser, a la postre, portadores del virus VIH, ignorándose científicamente por aquel entonces, si la transfusión sanguínea era un medio idóneo de contagio.

3. Casos de daños causados por un miembro indeterminado de un grupo. Aplicando la teoría de la equivalencia de condiciones es imposible alcanzar conclusión alguna acerca de la relevancia sobre

\footnotetext{
${ }_{96}$ Piaggio (n. 28).

${ }^{97}$ La conducta es causa del evento sólo si, eliminada ella, el suceso no se habría verificado -formula positiva- y un comportamiento no es causa cuando sin él, el evento igualmente se habría consumado -formula negativa-. STELLA (n. 77), p. 6.

${ }^{98}$ Antolisei (n. 89), p. 20 e ss.
} 
la participación causal de cada uno de los integrantes de la colectividad.

4. Casos de daños por omisión. Va de suyo que la abstención del omitente no es causa (material), ni condición necesaria del daño.

b) La necesidad de recurrir a ulteriores "correctivos".

La distinción entre causalidad e imputación

Resulta imprescindible recurrir, entonces, a un "ulterior correctivo" que permita tanto adecuar como modular (ya sea por ampliación o reducción) los excesos de la conditio sine qua non. Por tanto, la distinción entre causalidad e imputación constituye el punto nodal de la investigación causal. En palabras de Fernando Pantaleón:

"el Derecho no pude sino partir de un concepto de causalidad propio de la lógica y de las ciencias de la naturaleza (...). Los operadores jurídicos no son productores sino consumidores de las leyes causales (...). Por el contrario, el problema de la imputación es una cuestión claramente jurídica (...)”.

Debemos preocuparnos, sostiene Adriano de Cupis,

"de averiguar no ya cuando el daño pueda decirse producido por un hecho humano según las leyes de la naturaleza, sino más bien cuando ese daño pueda decirse jurídicamente producido por un hecho humano" $"$.

En este orden, se torna imprescindible dividir el juicio de constatación causal en dos fases, secuencias o estadios:

1) PRIMERA FASE (questio facti): la fijación del nexo causal en su primera secuencia tiene carácter indefectiblemente fáctico, es libre de valoraciones jurídicas y, por lo general, se realiza según el criterio de la conditio sine qua non.

2) SEGUNDA FASE (questio iuris): una vez explicada la causa del daño en sentido material o científico es menester realizar un juicio de orden jurídico-valorativo, a los efectos de establecer si el resultado dañoso causalmente imbricado a la conducta del demandado, puede o no serle objetivamente imputado ${ }^{100}$.

${ }^{99}$ Adriano de CupIs, Il danno. Teoria generale della responsabilità civile, $3^{\mathrm{a}}$ ed., Milano, Giuffrè editore, 1979, vol. 1, p. 217.

${ }^{100}$ Marco CAPECCHI, "Responsabilità civile e interruzione del nesso causale", in Danno e Respesponsabilità, No 5, Milano, 2006, p. 522. 
El primer juicio constituye un límite mínimo, aunque no excluyente, del juicio de indagación causal; ya que en algunos casos, aún comprobado que la conducta del encartado fue una de las causas físicas del menoscabo, no cabe imputárselo jurídicamente o, viceversa, supuestos en que se imputa el daño al demandado, no obstante que su accionar no fue condición necesaria para su producción.

\section{c) Imputación objetiva. Origen.}

Criterios de imputación

Se dice que esta doctrina, cuyos orígenes se remontan a los estudios del civilista hegeliano Karl Larenz ${ }^{101}$ y más tarde por el penalista Richard Honig ${ }^{102}$, no es precisamente una teoría, en el sentido de que configure un cuerpo armónico de proposiciones teóricas homogéneas. Más bien es el nombre con el que hoy son aglutinados diversos principios delimitadores o correctivos de la tipicidad de una conducta punible ${ }^{103}$.

La imputación objetiva consiste precisamente en suministrar criterios que permitan guiar correctamente el proceso de valoración normativa o ponderación entre las distintas causas o riesgos concurrentes a fin de poder atribuir objetivamente las consecuencias dañosas del hecho al posible responsable.

166 Por su parte, pese a que la doctrina lleva años discutiendo tópicos sobre imputación, se toman como base, aunque con algunas pequeñas discordancias, las propuestas trazadas por el penalista alemán Günther Jakobs ${ }^{104}$. Así, entre los distintos criterios de imputación (o mejor dicho, de "no imputación"), se destacan:

1) El criterio de adecuación o teoría de la causalidad adecuada,

2) el principio del incremento del riesgo,

3) la prohibición de regreso o posición de garante,

4) el ámbito de protección de la norma,

${ }^{101}$ Karl LaRENZ, Hegel Zurechnungslehre und der Begriff der objektiven Zurechnung, Leipzig, Scienta Verlag, 1927, p. 60. Aunque el término ‘imputación’ en su versión moderna asoma por primera vez en Samuel PufEndorf, De jure naturae et gentium libri octo, citado en AndreaRafaelle CASTALDO, La imputación objetiva en el delito culposo de resultado, Buenos Aires, Euros editores, 2008, p. 64; véase también: García-Ripoll Montijano (n. 83) capítulo primero, p. 1 y ss.

${ }^{102}$ Richard Honig, "Kausalität und objektive Zurechnung”, in Festsgabe für Reinhard v. Frank, Tübingen, Scienta Verlag, 1930, volumen I, p. 174.

${ }^{103}$ Marcelo SAncinetri, "Observaciones sobre la teoría de la imputación objetiva”, en AA.VV., Teorías actuales en el Derecho Penal, $75^{\circ}$ Aniversario del Código Penal, Buenos Aires, Ad-Hoc, 1998, pp. 181-198.

${ }^{104}$ Günther JAKoBs, La imputación objetiva en el derecho penal, Buenos Aires, Ad Hoc, 1994, p. 90. 
5) el principio de confianza y

6) el consentimiento de la víctima y la asunción del propio riesgo.

Finalmente, debe tenerse presente que los criterios de imputación no son dogmas absolutos, sino tópicos de impreciso halo, en cuanto condensan juicios de valor, muchas veces contradictorios y de difícil aprehensión ${ }^{105}$. A su vez, el hecho de que sean comunes a la responsabilidad penal y civil, no implica necesariamente que las consecuencias resultantes de la aplicación de los mismos hayan de ser idénticas en uno y otro ámbito $^{106}$.

\section{$\S$ IV. Causalidad PRobabilística \\ 1. El ocaso de la certeza absoluta como criterio de apreciación valorativo del nexo causal}

a) El fin de un viejo, injusto y utópico dogma

Atrás ha quedado aquella vieja concepción que exigía certeza absoluta para tener por acreditado el nexo de causalidad entre la conducta del encartado y el evento lesivo. Según sus cultores, el presupuesto causal sólo se tenía por probado, si en la indagación retrospectiva de los hechos que efectuaba el intérprete (vía hipotética), surgía de manera irrefutable que el comportamiento del agente era la causa del menoscabo.

No vamos a explayarnos aquí sobre los argumentos que esbozaban quienes defendían a ultranza esta tesis radical del "todo o nada"; dado que éstos han caído en desuso y, salvo contadas excepciones, asistimos a la consolidación de una nueva forma de apreciar el fenómeno causal, con importantes aportes interdisciplinarios y, por sobre todo, reconociendo una cierta dosis de incertidumbre, azar o aleatoriedad; a punto tal que hoy se habla, sin añadiduras, de causa probabilística ${ }^{107}$.

Actualmente podemos afirmar, sin mayores recovecos, que existe consenso sobre que:

1. La ciencia contemporánea se funda sobre verdades hipotéticas no incontrovertibles.

2. Nadie puede decir con absoluta certeza lo que habría ocurrido si el accionado hubiera actuado de otra manera.

3. La causalidad no admite prueba matemática.

${ }^{105}$ Pantaleón Prieto (n. 29), p. 1.591.

${ }^{106}$ Op. cit, p. 1.577.

${ }^{107}$ Benito Frosini, Le prove statistiche nel proceso civile e nel proceso penale, Milano, Giuffrè editore, 2002, p. 1 e ss. 
4. La teoría de la causalidad adecuada (estructurada bajo un sistema de regularidad estadística) no puede menos que contentarse con una fuerte o suficiente dosis de probabilidad.

5. La valoración de la prueba es libre y parte de un juicio de probabilidades y deducciones que no siempre llevan a la verdad plena.

b) La relectura de la causalidad en clave probabilística

Queda claro que la certeza absoluta, como criterio de apreciación valorativo de la causalidad, ciñó en aras de la probabilidad. La causalidad se rediseñó, entonces, en términos de probabilidad. Por tanto, el juez puede fundar su decisión sobre los hechos que, aun sin estar establecidos de manera irrefutable, aparecen como más verosímiles; es decir, que presentan un grado de probabilidad predominante, suficiente, alta, cualificada, etcétera.

En el Common Law goza de gran predicamento la máxima more probable than not, en cuya virtud, basta contar con una probabilidad superior al $50 \%$ para concluir que la causa imputable al demandado es plausible de producir el resultado dañoso. La jurisprudencia italiana e inglesa sigue también, con frecuencia, esta orientación probabilística, aunque con distintos criterios en los casos donde no se supera el umbral de certeza necesario para el progreso total de la acción (por ejemplo, 50\%, 75\%, 90\%, etc.); esto es, 168 para un sector, en todos aquellos supuestos en que el umbral de certeza es inferior al estipulado (por ejemplo, 49\%, 74\%, 89\%, etc.), corresponde rechazar el reclamo indemnizatorio; mientras que para otros, corresponde acoger parcialmente la pretensión y resarcir el daño, en proporción a la incidencia causal que la conducta, situación o estado del encartado tuvo en la producción del evento, tomando como límite porcentual un piso del $5 \%$ o $10 \%$.

c) El juicio de probabilidad: ¿̇se debe determinar en función de la previsión del sujeto?

Probabilidad significa verosimilitud, apariencia de verdad o cualidad de probable, esto es, que puede suceder. Previsibilidad es, por el contrario, cualidad de previsible ${ }^{108}$, es decir, todo aquello que puede ser previsto. Por otra parte, prever significa ver con anticipación, conocer o conjeturar por indicios o señales lo que ha de suceder, o disponer, preparar o ambos medios para futuras contingencias. A su vez, la previsibilidad requiere de una valoración ex ante a diferencia de la probabilidad que se determina ex post.

${ }^{108}$ Gérard Connu, Vocabulaire juridique, $8^{\circ}$ éd., Paris, Presses Universitaire de France, 2007, p. 717. 
Sostener que la causa adecuada es aquélla que aparece como probable, regular o previsible es, sin duda, determinar la probabilidad en función a la previsión del sujeto ${ }^{109}$. Bajo esta concepción negativa a extirpar la noción de previsión del sujeto como pauta de confronte necesaria del juicio de probabilidad, se enrolan distintas vertientes que van desde un juicio de adecuación netamente subjetivo, donde se analiza la capacidad de previsión del agente (Johannes von Kries), a un juicio de probabilidad sustentado en todo lo que era cognoscible para la generalidad de las personas (August Thon), o para un hombre destacadamente capaz e inteligente (Ludwig Traeger - Robert von Hippel).

Desde otra percepción, llamémosle favorable a no tener en consideración la previsión del agente, se ha sostenido una posición "ultraobjetiva" (Max von Rümelin), conforme a la cual en el juicio de probabilidad sólo deben tomarse en cuenta las circunstancias existentes al momento de la acción, fuesen ya conocidas en ese instante o solamente después. Sin embargo, su manifiesta semejanza con la teoría de la equivalencia de condiciones le han hecho plausible de sus mismos excesos.

Esta modalidad de comprobación del nexo causal sustentada en la previsibilidad del sujeto fue importada del ámbito del Derecho Penal, cuyo eje gira en derredor de la conducta del imputado, a diferencia del Derecho de la Responsabilidad Civil, cuyo punto cardinal se centra en el hecho dañoso. De ahí entonces, los vicios lógicos de este procedimiento en supuestos de responsabilidad objetiva, casos de incumplimiento contractual culposo, etcétera.

d) El juicio de probabilidad: ¿̇respecta a la valoración de la conducta o a la individualización de la causa?

Sostiene Renato Miccio:

"en rigor, cualquier cálculo sobre la previsibilidad o probabilidad del evento (...) viene en consideración a la valoración de la conducta y no a la búsqueda de la individualización de la causa, en cuanto estas expresiones no son otra cosa que componentes del área de reprochabilidad de la conducta, que a los efectos de la imputación del hecho va medida en base a la mayor o menor previsibilidad o excepcionalidad del evento dañoso (...). La búsqueda de la causa individual determinante no es ni probable ni improbable, sino individualizada o no individualizada" ${ }^{110}$.

${ }^{109}$ Ampliar en Alessandro GnANI, Sistema di responsabilità e prevedibilità del danno, Torino, Giappichelli, 2008, p. 199 e ss.

${ }_{110}$ Renato Miccio, I Diritti di crédito, Torino, UTET, 1973, vol. 2: Le fonti. Parte I, pp. 96, 103. 
La observación de Renato Miccio es cierta, aunque no por ello deja de ser parcial. Como ya dijimos, en la responsabilidad objetiva el nexo de causalidad adquiere una "configuración diferente", en tanto se traba entre la situación, hecho o actividad prevista por ley especial y el evento de daño, por ende, la valoración de la conducta del, a la postre, sindicado responsable, es total y absolutamente irrelevante.

Por tanto, puede concluirse que la noción de previsibilidad es conceptualmente ajena al juicio de probabilidad que postula la teoría de la adecuación y que se construye con los criterios de normalidad, habitualidad y regularidad. Sin embargo, cuando la responsabilidad se imputa a título subjetivo y el enlace causal se traba, por añadidura, entre la culpa y el evento, la valoración de la conducta del sujeto se cuela perspicazmente, en tanto y en cuanto la previsibilidad integra la culpa, y la culpa, es el asiento (plafón o peldaño) sobre el cual se construye el nexo causal ${ }^{111}$.

e) El papel de la prueba estadística en el juicio causal

Cierto es que, en múltiples ocasiones, la prueba estadística es de gran utilidad para el intérprete, siempre y cuando, claro está, la utilice con la cautela y previsión necesaria, para no transformar vagas informaciones en 170 leyes estadísticas o, viceversa, para no utilizar como claves referenciales informaciones altamente inciertas ${ }^{112}$.

Por decirlo de otro modo, el método estadístico no utilizado con elevada competencia puede conducir a falacias, no siempre perceptibles con facilidad. La evidencia estadística por sí misma, despojada del caso en concreto, no puede constituir el plafón de una decisión, ni aun en un proceso civil; requiere necesariamente de la presencia de pruebas vinculadas con el suceso específico.

De allí que, entonces, sea necesario distinguir entre dos nociones de probabilidad; por un lado, la probabilidad estadística, basada en una verificación empírica y porcentual de una sucesión determinada de eventos; por el otro lado, la probabilidad lógica, consiste en el grado de verosimilitud o credibilidad que puede ser atribuido a la hipótesis formulada al caso en concreto $^{113}$. Por consiguiente, la probabilidad estadística es un elemento instrumental, un componente más al que el juzgador podrá echar mano para poder arribar a un juicio de probabilidad lógica o credibilidad racional.

${ }^{111} \mathrm{Al}$ respecto, véase Gamarra - Gamarra (n. 87), p. 53 y ss.

${ }^{112}$ Michele TARuffo, "La prova dei fatti giuridici. Nozioni generale, Nozioni generali", in Antonio Cicu, Francesco Messineo (Diretto da), Trattato di Diritto civile e commerciale, continuato da Luigi Mengoni, Milano, Giuffre editorè, 1992, vol. III, tomo 2, sezione 1, p. 198.

${ }^{113}$ Massimo Donini, "La causalità omissiva e l'imputazione per l'aumento del rischio", in Rivista Italiana di Diritto e Procedura Penale, No 1, Milano, 1999, p. 49. 


\section{$\S \mathrm{V}$. Conclusiones}

Es común opinión en los ordenamientos jurídicos de tradición romano-germánica que la "relación de causalidad" entre la conducta (comportamiento, situación o estado) del demandado y el evento dañoso, es un elemento o requisito imprescindible del Derecho de la Responsabilidad Civil y, por consiguiente, una condición esencial para que nazca la obligación de resarcir. Será, quizá, porque el sentido común se niega a admitir la existencia de un daño que deba ser soportado por quien no ha contribuido de alguna manera a su realización.

A su vez, una pléyade de circunstancias (véase acápite $\S$ I in extenso) hacen que el nexo causal se erija, tanto desde el punto de vista teórico como del práctico, en el presupuesto más problemático de la responsabilidad civil.

Sin embargo, la distinción entre "causalidad" e "imputación objetiva" resurgida en los últimos años, de gran predicamento en el Derecho Penal, viene aportando un halo de aire fresco a nuestra materia que no podemos soslayar. Es que el Derecho no puede sino partir del concepto de causalidad propio de las Ciencias Naturales. No hay un concepto jurídico de causalidad, sencillamente no existe.

Así, una vez disociada la causalidad de la imputación, la indagación tiene dos fases; en la primera, la fijación del nexo causal tiene carácter indefectiblemente fáctico; libre de valoraciones jurídicas y, por lo general, se realiza según el criterio de la equivalencia de condiciones. Esta primera etapa constituye un límite mínimo, aunque no excluyente, del juicio de perquisición causal; pues en algunos casos, aun comprobado que la conducta del encartado fue una de las causas físicas del menoscabo, no cabe imputárselo jurídicamente o, viceversa, supuestos en que se imputa el daño al demandado, a pesar de que su accionar no fue condición necesaria para su producción.

En la segunda etapa, resulta imprescindible recurrir a un ulterior correctivo que permita tanto adecuar como modular (ya sea por ampliación o reducción) los excesos de la conditio sine qua non. De ahí entonces, que la distinción entre causalidad e imputación se haya erigido en el punto nodal de la indagación retrospectiva; en tanto debemos preocuparnos de averiguar no ya cuando el daño pueda decirse producido por un hecho humano según las leyes de la naturaleza, sino, más bien, cuando ese daño pueda decirse jurídicamente producido por un hecho humano.

Pero además, se asiste hoy a una nueva forma de apreciar el fenómeno causal, con importantes aportes interdisciplinarios y, por sobre todo, reconociendo una cierta dosis de incertidumbre, azar o aleatoriedad. Se observa una clara relectura de la causalidad en clave probabilística. 
Con todo, la causalidad, la imputación y la culpabilidad aún conservan confines borrosos. Será que asiste razón a José López Jacoiste cuando dice (en grafica alusión a cómo opera cada uno de los presupuestos) que:

"la causa embebe a la culpa, la culpa luce como acción, la acción expresa, mide $y$, en ocasiones, viene a ser el propio daño, el daño evoca, denuncia y presume culpa, la causa se intuye y desprende del propio daño, y el daño acaba postulando resarcimientos mediante cada vez más sutiles y lábiles enlaces con otros presupuestos cuya exigencia tornase de día en día muchos menos real, mucho más virtual" ${ }^{114}$.

En otras palabras,

"la secuencia [evento dañoso - responsabilidad - obligación de resarcir] se presenta como una verdadera aporía; puesto que el juicio de responsabilidad es, al mismo tiempo, condición de la relevancia jurídica del evento dañoso y presupuesto para su conexión con un determinado sujeto responsable, o sea que podemos decir que un sujeto ha causado un daño solo después de haber decidido que es responsable"115.

\section{BiBLIOGRAFÍA}

Aberkane, Hassen, "Du dommage cause par une personne indeterminée dan un groupe", dans RTDciv., spècial, No 29, Paris, 1958.

ACCIARRI, Hugo, La relación de causalidad y las funciones del Derecho de daños. Reparación, prevención, minimización de costos sociales, Buenos Aires, Abeledo Perrot, 2009.

AcuTis, Maurizio de, "La solidarità nella responsabilità civile", in Rivista di Diritto Civile, vol. II, Padova, 1975.

Alpa, Guido, Trattato di Diritto civile, Milano, Giuffrè editore, 1999, tomo IV: La responsabilità civile,

Antolisei, Francesco, Il rapporto di causalità nel diritto penale, Torino, Giappichelli, 1960 .

${ }^{114}$ José López Jacoiste, “Cien años de horizonte extracontractual”, en Centenario del Código Civil, Madrid, Asociación de Profesores de Derecho Civil, Centro de Estudios Ramón Areces, 1990, tomo II, p. 1.162.

115 Vicente Montés Panadés, "Causalidad, imputación objetiva y culpa en la concurrencia de culpas”, en Antonio Cabanillas SáncheZ (coord.), Estudios jurídicos en homenaje al profesor Luis Diez Picazo, Derecho civil. Derecho de obligaciones, Madrid, Thomson-Civitas, 2003, tomo II, p. 2.592. 
Araya Jasma, Fernando, La relación de causalidad en la responsabilidad civil, Santiago, LexisNexis, 2003.

AtAz LÓPEz, Joaquín, "Las wrongful actions en material de responsabilidad médica", en Antonio Orti Vallejo (dir.) María Carmen García Garnica (coord.), La responsabilidad civil por daños causados por servicios defectuosos, Navarra, ThomsonAranzadi, 2006.

BANAKas, Stathis, "Causalité juridique et imputation: réflexions sur quelques développements récents en Droit anglais", in Revue Lamy Droit Civil, N $^{\circ} 40$, Paris, 2007.

Baudouin, Jean-Louis, Deslauriers, Patrice, La responsabilité civile, Québec, Éditions Yvos Blais, 2007, vol. 1: Principes généraux.

Beaudeux, Cédric, Causalité, fondement pour une theorie générale de la responsabilité civile, thesè, Strasbourg, Université Robert Schuman de Strasbourg III, 2006.

Belvedere, Andrea, "Causalità giuridica?", in Rivista di Diritto Civile, vol. I, Padova, 2006.

Bénabent, Alain, La chance et le Droit, Paris, Librairie Générale de Droit et de Jurisprudence, 1973.

Brebisa, Roberto, La relación de causalidad en el derecho civil, Rosario, Juris, 1975.

Brun, André, Responsabilité civile extracontractuelle, Paris, Litec, 2005.

Calvo Costa, Carlos, Derecho de las obligaciones, Buenos Aires, Hammurabi, 2010, tomo 2: Derecho de daños.

CAncelier, Guillaume, "De l'explication causale en Droit de la responsabilité civile délictuelle", in RTDciv., $\mathrm{N}^{\mathrm{O}}$ 1, Paris, 2010.

CAPECCHI, Marco, Il nesso di causalità. Da elemento della fattispecie "fatto illecito" a criterio di limitazione del risarcimento del danno, $2^{\mathrm{a}}$ ed., Padova, Cedam, 2005.

CAPECCHI, Marco, "Responsabilità civile e interruzione del nesso causale", in Danno e Responsabilità, No 5, Milano, 2006.

Carbone, Vincenzo, Il fatto dannoso nella responsabilità civile, Napoli, Jovene, 1969.

Carbonnier, Jean, Droit civil, 15 a éd., Paris, Presses Universitaires de France, 1991, volume 4: Les obligations.

Castaldo, Andrea-Rafaelle, La imputación objetiva en el delito culposo de resultado, Buenos Aires, Euros editores, 2008.

Conte, Philippe, Patrick Maistre du Chambon, La responsabilité civile délictuelle, Grenoble, Presses Universitaires de Grenoble, 2000.

Connu, Gérard, Vocabulaire juridique, $8^{\circ}$ éd., Paris, Presses Universitaire de France, 2007.

Corsaro, Luigi, Tutela del danneggiato e responsabilità civile, Buenos Aires, La Ley, 2005.

CupIs, Adriano de, "Il problema giuridico del 'quantum respondeatur'", in Rivista di Diritto Civile, vol. I, Padova, 1967. 
Cupis, Adriano de, Il danno. Teoria generale della responsabilità civile, $3^{\mathrm{a}}$ ed., Milano, Giuffrè editore, 1979, vol. 1.

Chabas, François, L'influence de la pluralité de causes sur le Droit a réparation, Paris, Librairie Générale de Droit et de Jurisprudence, 1967.

Chabas, François, "La responsabilità delle strutture sanitarie per difetto di organizzazione. Studio di diritto privato francese", in Responsabilità Civile e Previdenza, No 1, Milano, 2001.

Deroussin, David, Histoire du Droit des obligations, Paris, Economica, 2007.

Descamps, Olivier, Les origines de la responsabilité pour faute personnelle dans le Code civil de 1804, Paris, Librairie Générale de Droit et de Jurisprudence, 2005.

Domínguez ÁGUILA, Ramón, La causalité dans la responsabilité en Droit comparé francais et chilien, thesè, Toulousse, Université de Toulouse, 1967.

Donini, Massimo, "La causalità omissiva e l'imputazione per l'aumento del rischio", in Rivista Italiana di Diritto e Procedura Penale, No 1, Milano, 1999.

Durry, Georges, "Commentaires sur l'échec de la division civile $\left(2^{\mathrm{e}}\right)$ de la cour d'appel. 2 ${ }^{\circ}, 12 / 12 / 1968$ ”, in RTDciv., N 1, Paris, 1969.

Echevesti, Carlos, La culpa, Buenos Aires, Hammurabi, 1997.

Esmein, Paul, "Le nez de Cléopâtre ou les affres de la causalité", Dalloz, Chronique, Paris, 1964.

174 FAgnart, Jean-Luc, La causalité, Belgium, Kluwer, 2009.

FAVIER, Joseph, La relation de cause à effet dans la responsabilité quasi délictuelle, thèse, Paris, 1951.

Fischer, Jérôme, "Causalité, imputation, imputabilité: Les liens de la responsabilité civile”, in oeuvrage collectif, Libre Droit. Mélanges en l'honneur de Philippe le Tourneau, París, Dalloz, 2008.

Forchielli, Paolo, Il rapporto di causalità nell'illecito civile, Cedam, Padova, 1960.

Forchielli, Paolo, Responsabilità civile. Lezioni, Padova, Cedam, 1968.

Frosini, Benito, Le prove statistiche nel proceso civile e nel proceso penale, Milano, Giuffrè editore, 2002.

García-Ripoll Montuano, Martín, Imputación objetiva, causa próxima y alcance de los daños indemnizables, Granada, Comares, 2008.

GazZAniga, Jean-Louis, Introduction historique au Droit des obligations, Paris, Presses Universitaires de France, 1992.

GERI, Vinicio, Responsabilità civile per danni da cose ed animali, Milano, Giuffrè editore, 1963.

Gnani, Alessandro, Sistema di responsabilità e prevedibilità del danno, Torino, Giappichelli, 2008.

Goldenberg, Isidoro, La relación de causalidad en la responsabilidad civil, Buenos Aires, La Ley, 2000. 
GorlA, Gino, "Sulla cosiddetta causalità giuridica: 'fatto dannoso e conseguenza”, in Studi in onore di Antonio Cicu, vol. 1, Milano, Giuffrè editore, 1951

Grare, Clothilde, Recherches sur la cohérence de la responsabilité délictuelle. L'influence des fondements de la responsabilité sur la réparation, Paris, Dalloz, 2005.

GuEx, Robert, La relation de cause à effet dans les obligations extra-contractuelles, thèse, Lausanne, Universite de Lausanne, Imprimerie Charles Pache, 1904.

Hart, Herbert, Tony Honoré, Causation in the Law, Oxford, Clarendon Press, 1985 (la $1^{\text {a }}$ edición data del año 1959).

Honig, Richard, "Kausalität und objektive Zurechnung”, in Festsgabe für Reinhard v. Frank, Tübingen, Scienta Verlag, 1930, volumen I, p. 174.

Infante Ruiz, Francisco, La responsabilidad por daños. Nexo de causalidad y causas hipotéticas, Valencia, Tirant Lo Blanch, 2002.

JАковs, Günther, La imputación objetiva en el derecho penal, Buenos Aires, Ad Hoc, 1994.

Kelsen, Hans, Sociedad y naturaleza. Una investigación sociológica, Buenos Aires, Depalma, 1945.

LARENZ, Karl, Hegel Zurechnungslehre und der Begriff der objektiven Zurechnung, Leipzig, Scienta Verlag, 1927.

Lapoyade-Deschamps, Christian, "La reparation du préjudice économique pur en Droit français", dans Revue Internationale de Droit comparé, No 2, Paris, 1998.

LEDuc, Fabrice, "Causalité civile et imputation, en Les distorsions du lien de causalité en droit de la responsabilité civile", dans Actes du Colloque des 15 et 16 décembre 2006, Faculté de Droit et de Science Politique de Rennes, supplement spécial, Revue Lamy Droit Civil, No 7, Paris, 2007.

López Herrera, Edgardo, Teoría general de la responsabilidad civil, Buenos Aires, LexisNexis, 2006.

López Jacoiste. José, “Cien años de horizonte extracontractual”, en Centenario del Código Civil, Madrid, Asociación de Profesores de Derecho Civil, Centro de Estudios Ramón Areces, 1990, tomo II.

Lorenzo, Miguel-Federico de, El daño y las causas de justificación. A propósito del Proyecto de Código Civil de 1998, Buenos Aires, La Ley, 2000-C.

Luna Yerga, Álvaro, La prueba de la responsabilidad civil médico-sanitaria. Culpa y causalidad, Madrid, Civitas, 2004.

LlambíAs, Jorge, "El Derecho no es una física de las acciones humanas", en La Ley, tomo 107, Buenos Aires, 2009.

Maiorca, Carlo, "Colpa civile", in Enciclopedia del Diritto, Milano, Giuffrè editore, 1960, vol. 7.

MARInACCIO, Alessandro, "Esposizione ad amianto ed insorgenza di casi di mesotelioma maligno. Evidenze epidemiologiche e causalità", in Roberto PucELLA, Giovanni de SAntis, Il nesso di causalità. Profili giuridici e scientifici, Padova, Cedam, 2007. 
Marteau, Patrice, La notion de causalité dans la responsabilité civile, thèse, Aix-enProvence, Aix, 1913.

Matteis, Raffaella de, La responsabilitá medica, Padova, Cedam, 1996.

Matteis, Raffaella de, Responsabilità e servizi sanitari. Modelli e funzioni, Padova, Cedam, 2009.

MaInguy, Daniel, "Le traitement juridique des infections nosocomiales", en Antoine LeCA et François Vialla, Le risque épidémique. Droit, histoire, médicine et pharmacie, Aix-en-Provence Marseille, Presses Universitaires d'Aix-Marseille, 2003.

MAYO, Jorge, "Responsabilidad civil por los daños causados por cosas inertes", en Alberto Bueres (dir.) - Elena Higthon (coord.), Código Civil y normas complementarias. Análisis doctrinario y jurisprudencial, Buenos Aires, Hammurabi, 1999, tomo 3A.

Mayo, Jorge, Estudios de Derecho civil, Buenos Aires, La Ley, 2005.

Mazeaud, Denis, "Famille et responsabilité (Réflexions sur quelques aspects de 'l'idéologie de la réparation')", dans Études offertes à Pierre Catala. Le Droit privé français à la fin du XX siècle, Paris, Litec, 2001, volume I: Partie générale.

Miccio, Renato, I Diritti di crédito, Torino, UTET, 1973, vol. 2: Le fonti. Parte I.

Mignon, Maxime, "Le fondement juridique de la responsabilité civile des médecins et chirurgiens", in Dalloz, No I, Paris, 1950.

Mignot, Marc, "Les obligations solidaires et les obligations in solidum” en Droit privé français, Paris, Dalloz, 2002.

Mislawski, Roger, La causalité dans la responsabilité civile. Recherches sur ses rapports avec la causalité scientifique, thesè pour le doctorat de la Université de CergyPontoise, Paris, 2006.

Monateri, Pier-Giuseppe, Trattato di diritto civile. Le fonti della obbligazioni, Torino, Utet, 1998, vol. 3: La responsabilità civile.

Montés Panadés, Vicente, "Causalidad, imputación objetiva y culpa en la concurrencia de culpas”, en Antonio Cabanillas SÁnchez (coord.), Estudios jurídicos en homenaje al profesor Luis Diez Picazo, Derecho civil. Derecho de obligaciones, Madrid, Thomson-Civitas, 2003, tomo II.

Mosset Iturraspe, Jorge, Responsabilidad por daños, Santa Fe, Rubinzal Culzoni, 2004 .

NAdEAu, Alain, "Notes sur le lien de causalité et sa preuve dans les actions en responsabilité civile", dans UnIversité DE MonTrÉAL, Études juridiques en hommage à Monsieur le juge Bernard Bissonnette, Montréal, Presses de l'Université de Montréal, 1963.

Nguyen Thanh Nha, Jacqueline, "L'influence des prédispositions de la victime sur l'obligation á reparation du défendeur á l'action en responsabilité", in $R T D$ civ., $\mathrm{N}^{\circ} 75$, Paris, 1976.

PALUdi, Osvaldo, La relación de causalidad en la responsabilidad civil por el hecho propio, Buenos Aires, Astrea, 1976. 
Pantaleón Prieto, Fernando, "Causalidad e imputación: criterios de imputación”, en Centenario del Código Civil, Madrid, Asociación de Profesores de Derecho Civil, Centro de Estudios Ramón Arces, 1990, tomo II.

Penneau, Jean, La responsabilité du medicin, Paris, Dalloz-Sirey, 1992.

Piaggio, Aníbal, "Azar y certeza en el Derecho de Daños”, en El Derecho, vol. 152, Buenos Aires, 2005.

Piaggio, Aníbal, "Presencias de la culpa", en La Ley, tomo F, Buenos Aires, 2005.

Pietrobon, Vittorino, Illecito e fatto illecito, Padova, Cedam, 1998.

Ponzanelli, Giulio, La responsabilità civile. Profili di diritto comparato, Bologna, Il Mulino, 1996.

Ponzaneldi, Giulio, "I problema della tutela risarcitoria da fumo attivo", in Responsabilità Civile e Providenza, N 4-5, Milano, Giuffrè editore, 2005.

Postacioglu, IIhan, "Les faits simultanes et le probleme de la responsabilité collective", dans RTDciv., No 3, Paris, 1954.

PucElla, Roberto, La causalità incerta Torino, Giappichelli editore, 2007.

Pufendorf, Samuel, De jure naturae et gentium libri octo, citado en Andrea-Rafaelle Castaldo, La imputación objetiva en el delito culposo de resultado, Buenos Aires, Euros editores, 2008.

Quezel-Ambrunaz, Christophe, Essai sur la causalité en Droit de la responsabilité civile, Paris, L.G.D.J., 2010.

Realmonte, Francesco, Il problema del rapporto di causalità nel risarcimento del danno, Milano, Giuffrè editore, 1967.

RIPERT, Georges, La règle morale dans les obligations civiles, $3^{\mathrm{a}}$ éd., Paris, Librairie Générale de Droit et de Jurisprudence, 1935.

Rossello, Carlo, Il danno evitabile, Padova, Cedam, 1990.

SABARD, Olivia, La cause étrangère dans les Droits privé et public de la responsabilité extracontractuelle, Paris, Librairie Générale de Droit et de Jurisprudence, 2007.

SAlEILles, Raymond, Essai d'une théorie générale de l'obligation: d'après le projet de Code Civil allemand, Paris, Librairie F. Pichon successeur, 1890.

SALvi, Cesare, Il danno extracontrattuale. Modelli e funzioni, Napoli, Jovene, 1985.

SAlvi, Cesare, La responsabilità civile, Milano, Giuffrè editore, 1998.

SAncinetTi, Marcelo, "Observaciones sobre la teoría de la imputación objetiva", en AA.VV., Teorías actuales en el Derecho Penal, $75^{\circ}$ Aniversario del Código Penal, Buenos Aires, Ad-Hoc, 1998.

SAVATiER, René, "Une faute peut'elle engendrer la responsabilité d'un dommage sans l'avoir causé?", dans Dalloz, No 2, Paris, 1970.

Simone, Roberto, "La responsabilità della struttura sanitaria pubblica e privata", in Danno e Responsabilità, N $^{\circ}$ 1, Milano, Ipsoa Editore, 2003.

Sourdat, Auguste-Jean-Batiste, Traité général de la responsabilité ou de l'action en dommages-intérêts en dehors des contrats, avec la collaboration de Louis Sourdat, $5^{\mathrm{a}}$ éd. revue et augmentée, Paris, Marchal \& Billard, 1902, volume 1. 
Starck, Boris, Henri Roland, Laurent Boyer, Obligations, $5^{\text {a }}$ éd., Paris, Litec, 1996, tome 1: Responsabilité délictuelle.

Stella, Federico, Leggi scientifiche e spiegazione causale nel Diritto penale, $2^{\mathrm{a}}$ ed., Milano, Giuffrè editore, 2000.

TACChini-Laforest, Valèrie, "Reflexion à propos de la perte d' une chance", in Petites Affiches, No 20, Paris, 19 Julliet, 1999.

TAPInOs, Daphné, Prévention, précaution et responsabilité civile. Risques avéré, risqué suspecté et transformation du paradigme de la responsabilité civile, Paris, Harmattan, 2008.

TARuffo, Michele, "La prova dei fatti giuridici. Nozioni generale, Nozioni generali", in Antonio Cicu, Francesco Messineo (Diretto da), Trattato di Diritto civile e commerciale, continuato da Luigi Mengoni, Milano, Giuffre editorè, 1992, vol. III, tomo 2 , sezione 1 .

Thibierge, Catherine, "Libres propos sur l'evolution du Droit de la responsabilité (vers un élargissement de la fonction de la responsabilité civile?)", dans RTDciv., No 3, Paris, 1999.

Thouvenin, Dominique, La responsabilité médicale, Paris, Médecine-Sciences Flammarion, 1995.

Toвías, José, "La relación de causalidad en la responsabilidad civil médica", en Revista de Responsabilidad Civil y Seguros, s/vol., Buenos Aires, 2003.

Trimarchi, Pietro, Causalità e danno, Milano, Giuffrè editore, 1967.

178 VAlCAVI, Giovanni, "In torno al rapporto di causalità nel torto civile", in Rivista di Diritto Civile, No II, Padova, 1995.

VALCAVI, Giovanni, "Sulla causalità giuridica nella responsabilità civile da inadempienza e da illecito", in Rivista di Diritto Civile, No 2, Pavoda, 2001.

VALSECCHI, Emilio, "Responsabilità oggettiva aquiliana e caso fortuito", in Rivista di Diritto Commerciale, No I, Padova, 1947.

VINCENT, Jean, "L'extension en jurisprudence de la notion de solidarité passive", dans RTDciv., N 4 , Paris, 1939.

Visintini, Giovanna (a cura di), I fatti illeciti, Padova, Cedam, 1999, vol. 3: Causalità e danno.

Williatte-Pellitteri, Lina, Contribution à l'élaboration d'un Droit civil des événements aléatoires dommageables, Paris, Librairie Générale de Droit et de Jurisprudence, 2009.

YzQuierdo Tolsada, Mariano, Sistema de responsabilidad civil, contractual y extracontractual, Madrid, Paris, Dykinson, 2001.

Zeno-Zencovich, Vincenzo, La responsabilità civile da reato. Lineamenti e prospettive di un sottosistema giurisprudenziale, Padova, Cedam, 1989.

Zeno-Zencovich, Vincenzo, La sorte del paziente, Padova, Cedam, 1994. 